\title{
Exploring Challenges of Web-Based Purchasing
}

\author{
Santhia Nadesan, Choo Wou Onn, Shahryar Sorooshian
}

\begin{abstract}
The main goal of the current article was to review challenges of online purchasing. Theoretically, this research has few benefits and has importance which the findings of this study will listing the crucial challenges that need to be addressed and tackled to achieve the success of E-commerce (and precisely electronic-shopping) in companies. It encourages additional utilization of technologies of Electronic-Commerce, styles the e-transaction practice at ease, boosts the amount of acknowledgement and adoption of this online technology, results in advancement of online customer responsibility, presents the loyalty concept, raise customer satisfaction, sustains longer-term relationship with clienteles and contributions to obtaining of competitive advantages.
\end{abstract}

Index Terms: Challenges, Online Shopping, Web, Literature Review.

\section{INTRODUCTION}

Electronic purchasing, also known as online shopping, is a business-to-consumer (B2C) method that comes under E-commerce that is used by many [1]. Electronic shopping is the action of services and goods being sold using the WWW (World Wide Web) as a medium [2]. In electronic shopping, the online stores serve their consumers more efficiently as it provides delivery services [3]. Many retailers and merchants show that they have interest and prefer in selling the products and also services via the internet because they know that online shopping have the capacity to establish as an alternative channel when contrasted to an old-fashioned retail networks such as physical retail supplies [4]. In retail industry, online shopping make the peoples' lives easier by allowing the customers to visit online retailers, choose the desired products, make payments over online fast cash transactions, vip or credit cards or also allowing them to pay once they receive their product which is known as cash on delivery. Quick growth in the quantity of computers and availability of internet access lead to the growth in electronic-commerce. This is one of the motives to conduct both shop online and business-related online activities [5]. The rapid advancement of e-commerce has made a very huge chances for economic profits for businesses in addition to online consumers. The Internet has made it simpler for new retail companies that enter the industry and existing retailers alike to set-up, dispatch, re-stage and update online stores. In

Manuscript published on 30 August 2019.

*Correspondence Author(s)

Santhia Nadesan, FIM, Universiti Malaysia Pahang, Pahang, Malaysia.

Choo Wou Onn, Faculty of Information Technology, INTI International University, Nilai, Malaysia.

Shahryar Sorooshian, ERAS, Universiti Malaysia Pahang, Pahang, Malaysia.

(C) The Authors. Published by Blue Eyes Intelligence Engineering and Sciences Publication (BEIESP). This is an open access article under the CC-BY-NC-ND license http://creativecommons.org/licenses/by-nc-nd/4.0/ any case, because the online shopping is changing and transforming rapidly, it displays its challenges.

\section{METHODOLOGY}

Google is the chief search engine to explore issued article and news. Hence, this study selects this search engine as the main source of databank to gather related papers for analysis. So, the main methodology of this work is a qualitative research.

\section{RESULT AND DISCUSSION}

Online customers and retailers are always has been worried about security [4]. The essential reasons referred to this a perceived absence of security and privacy of online customers' personal details, it could be bank details and fear of data fraud. Security can characterised as the protecting the information or data from individuals without any authorized approval [6]. Identity theft is also one of the security risks that online consumers and retailer concerned about. It happens when somebody steals all your personal data or information with intention to use the information to imitate another person to carry out crimes [7] In online business, it is vital to know the identity and personal information of the consumer or the business. In this manner, verification is very crucial in providing a secure internet shopping experience to both consumer and retailer. It is challenging to have a secure online shopping that has been prompting bad or negative results on the development and upgrading of web-based business. Numerous shoppers show their unwillingness to participate in purchasing online as a result of lack of trust and uncertain about the safety and confidentiality and protection of their personal and also financial data [8]. The chances of consumers visiting an online shopping site will decrease if they lost trust in the capacity of the website to protect their personal information like bank details [9]. It is impossible for the online consumers to making sure of the quality of the products by checking it physically and unable to confirm the safety of sending personal and money related information when purchasing online [10]. Internet utilization for purchasing a product is bounded by culture and the impacts of the adoption of online business from one nation then into the next. The percentage of similarity of the IT and the variety of usages with the good quality and the standards of a community impacts its implementation in that system [11]. One of the challenges which has been the limitation of the improvement of online business is identified with the behaviour or the culture of online consumers when they had to purchase goods and services using banking details [12]. The internet is not good with basic customers' behaviour of always wanted to visit the physical store that enables them to feel the item by touching and checking the quality of the product before buying it.

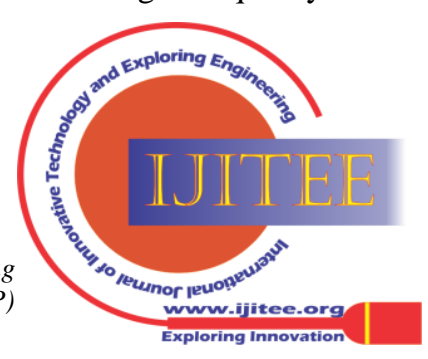




\section{Exploring Challenges of Web-Based Purchasing}

It is also same for the retailers who are prefers to sell their products and services through physical stores. When the customers are unable to assess the product before buying it become a hindrance for the development of online based shopping [13].

Personal computer entrance in the industry of e-commerce has been the essential determiner of availability for online shopping activities and having a personal computer has something to do with the profit $[14,15]$. Possibility of owning a personal computer among the poor and uneducated is very low in some rural areas such as estates. This situation is being a hindrance for PC penetration and consequently for the implementation of web-based purchasing. In some nations, where the web-based shopping is something normal and famous among the citizens, they utilize Mastercards or credit cards in making the financial payment during their online purchasing. Very less individuals have credit cards and potential consumers are afraid of being tricked [16].

The ISO (International Standards Organizations) has characterized availability as "the convenience of an item, the facility by people with the most stretched out scope of abilities". The quality of the accessibility of the online users legitimately has bring consequences to the satisfaction and customer loyalty [17]. 14 important components were recognised for developing an online shopping websites because the accessibility is very important to gain consumers' satisfaction [18]. Additionally, Cyr [19] explored the impact of online shopping website user accessibility system that includes factors all the basic access to know about the product [19]. These key factors are important to fulfill the trust in the website and satisfaction among the online customers who have different cultures [19] and not having a good electronic store accessibility has a bad outcome for the number of peoples purchasing online [20].

Perceived risk is the challenge that originates from the factor of security and fraud. The customers will gain proficiency with the handiness just as the dangers related with the innovation as they interact with newest innovation and technology. An internet business that is a virtual buying of goods and services can be connected with uncertainty in all the aspects and bring a perceived risk generally [21]. According to studies [21,22], online purchasers see online shopping as a risky thing to do, when compared to in-store purchasing. In the process of online shopping, there are two different components of perceived risk. Firstly, risk that is related with the service or product being purchased. Secondly, the risk is related with the online payment and transactions of money via the internet. This risk is not only because the online consumers afraid of losing the money during the transactions but they also worried more about losing all the financial information when using the credit cards to make the payment when purchasing online [23]. Generally, consumers are hesitant when it comes to taking decision in terms of paying online because there are higher possibilities of risky situations when compared with purchasing in-store. Perceived risk brings the most important challenge to the development of online retailing business. Although there many other challenges that directly influencing the adoption attitude on the web, perceived risks are challenges to the purchaser on the Internet. There is a risk where the person who supplies the goods may not deliver the goods that has been requested by the customer with much satisfaction, and it is believed to be risky. There is a chance that during the selection of the product, there could be inaccuracy and the product may never receive by the purchaser at the promised time [24]. Uncertainties among the customers about how the retailers are dealing with the customers' financial information will higher the perceived risk and lessen their ability to adopt web-based shopping.

Table 1 is presenting the summary of the reviewed literature in this field as well as the list of challenges of online shopping.

Table 1. Challenges of online shopping

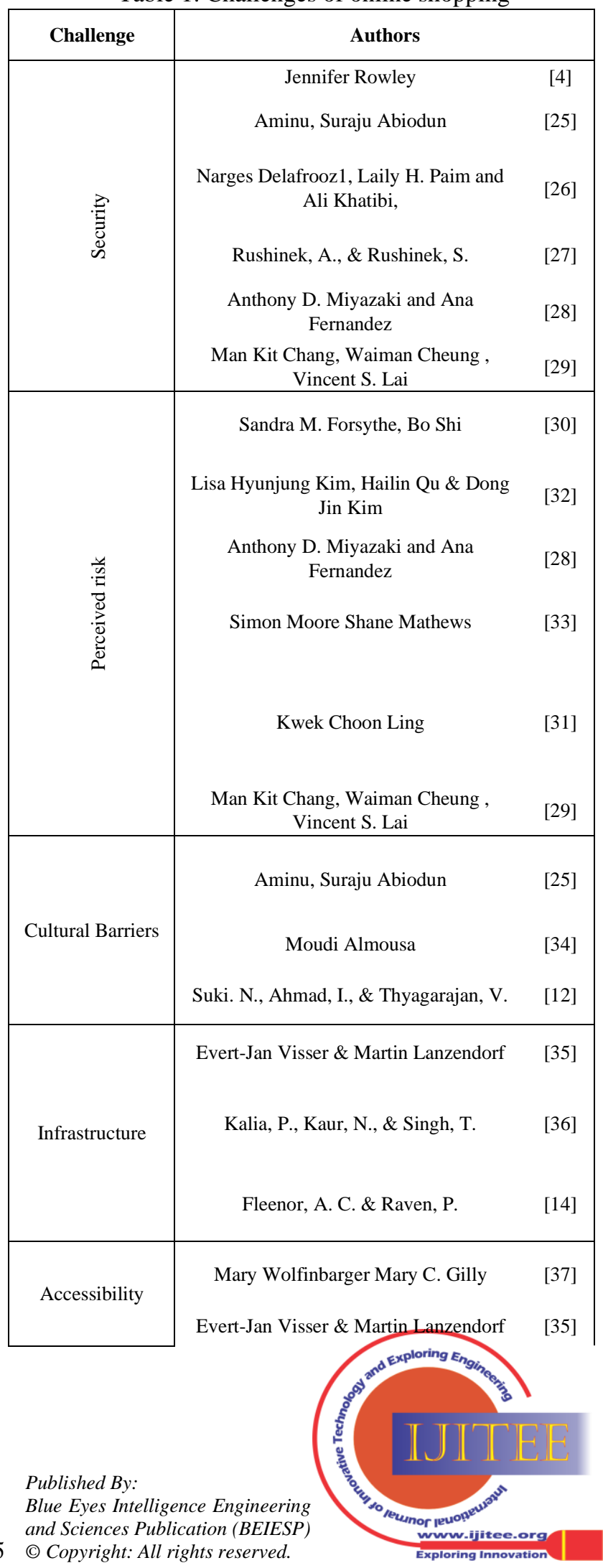




\begin{tabular}{|c|cc|}
\hline & \multicolumn{3}{|c|}{ Sendy F. \& Tim S., Martin D. \& Jan F. } & {$[20]$} \\
& \multicolumn{3}{|c}{ Cyr, D. } & {$[19]$} \\
\hline $\begin{array}{c}\text { Complex Tax } \\
\text { Laws }\end{array}$ & Kalia P., Kaur N., \& Singh T. & {$[36]$} \\
\hline $\begin{array}{c}\text { Availability of } \\
\text { information }\end{array}$ & Mary Wolfinbarger Mary C. Gilly & {$[37]$} \\
\hline & Noel Yee-Man S., and May Mei-Shan C. & {$[38]$} \\
\hline $\begin{array}{c}\text { Managing } \\
\text { customer } \\
\text { perceptions }\end{array}$ & Mark B.Kolesar and R.Wayne Galbraith & {$[39]$} \\
\hline
\end{tabular}

\section{CONCLUSION}

Online companies are sometimes unable to identify the possible challenges that they might have to face to be prepared for. This study was to identify retail-company challenges for online shopping adoption. The ways that online retailers are using not sufficiently to address the regularly changing customer demands and requirements to guarantee customer loyalty and satisfaction. In this way, it is vital to recognize the key challenges and furthermore the solution for it for the development or digitalization of the business.

Contribution Note: The work is part of a final year project by S.N.; S.S was supervising the project. Drafting of the article was with S.N., and C.W.O have edited and improved it. Corrections and response to the reviewers was with C.W.O. Financial support for this publication was with C.W.O. All authors agreed on the last version of the work.

\section{REFERENCES}

1. Ling, K. C., Chai, L. T., \& Piew, T. H. (2010). Effects of Shopping Orientations, online trust and prior online purchase experience. International Business Research, 3(3), 63-76

2. Awoyelu, I.O \& Tangba, O. (2010).Development of On-line Shopp ing Mart System for Developing Countries. 3(3), 164-173

3. Perea y Monsuwé, T., Dellaert, B. G. C., \& de Ruyter, K. (2004). What drives consumers to shop online? A literature review. International Journal of Service Industry Management, 102-121.doi:10.1108/09564230410523358

4. Rowley, J. (1996). Retailing and shopping. 24(3), 26-37.

5. Harn, A. C. P., Khatibi, A., \& Ismail, H. bin. (2006). E-Commerce: A Study on Online Shopping in Malaysia. Journal of Social Sciences, 13(3), 231-242. https://doi.org/10.1080/09718923.2006.11892554 Risk for Further E- commerce Security and Privacy Issues as a Potential Risk for Further E- commerce Development. (June).

7. Salam, A. F., Rao, H.R., \& Pegels, C. C. (2003). Consumer-perceived risk in ecommerce transactions. Communications of the ACM, 46(12), 325-331

8. Jones, S., Wilikens, M., Morris, P. and Masera, M. (2000), "Trust requirements in e-business", Communications of the ACM, Vol. 43 No. 2, pp. 81-7.

9. Niranjanamurthy, M. and Chahar, D. (2013). The Study of E -Commerce Security Issues and Solutions. International Journal of Advanced Research in Computer and Communication Engineering, 2(7)

10. Turban. E., King. D., Lee. J. K., Liang, T. P., and Turban, D.C., Perspective. 8th Ed.

11. Rogers, E. M. (1995). Diffusion of innovations (4th ed.). New York: The Free Press
6. Yazdanifard, R. (2011). Security and Privacy Issues as a Potential (2015), Electronic Commerce: A Managerial and Social Networks

12. Suki. N., Ahmad, I., \& Thyagarajan, V. (2002). Motivation and concern factors for internet shopping: A Malaysian perspective. The Electronic Journal for E-commerce Tools and Applications. 1, 1-18.

13. Al-Fadhli, S. [2011]. Critical success factors influencing e-commerce in Kuwait. Journal of Internet Banking and Commerce, 16(1). 1-7.

14. Fleenor, A. C. \& Raven, P. [2003]. Barriers to effective e-business in developing countries. International Business \& Economics Research Journal, 1(4), 39-48

15. Nizamuddin, S., \& Khalid, R. [2001]. Pakistan sustained effort in IT sector needed. Proceedings of Dawn Conf. on IT: The future of Pakistan, Karachi. Special sSpplement

16. Efendioglu, A. M., Yip, V. F., \& Murray, W. L. [2009]. E-commerce in developing countries: Issues and influences. San Francisco: University of San Francisco Press

17. Park, C. H., \& Kim, Y. G. (2003). Identifying key factors affecting consumer purchase behavior in an online shopping context. International Journal of Retail \& Distribution Management , 31(1) 16-29. https://doi.org/10.1108/09590550310457818

18. Tan, F. B., Tung, L., \& Xu, Y. (2009). A study of web-designers' criteria for effective business-to-customer (B2C) websites using the repertory grid technique. Journal of E-commerce Research, 10(3), $155-177$

19. Cyr, D. (2008). Modeling website design across cultures: Relationships to trust, satisfaction and e-loyalty. Journal of Management Information Systems, 24(4), 47-72

20. Farag, S., Schwanen, T., Dijst, M., \& Faber, J. (2007). Shopping online and/or in-store? A structural equation model of the relationships between e-shopping and in-store shopping. Transportation Research Part A: Policy and Practice, 41(2), 125-141. https://doi.org/10.1016/j.tra.2006.02.003

21. Tan, Soo Jiuan (1999), "Strategies for reducing consumers' risk aversion in Internet shopping," Journal of Consumer Marketing, 16 (2), $163-80$.

22. Donthu, Naveen and Adriana Garcia (1999), "The Internet Shopper," Journal of Advertising Research, 39 (3), 52-58.

23. Bhatnagar, A., \& Misra, S. (2014). On Risk , Convenience and Internet (May). https://doi.org/10.1145/353360.353371

24. Tian, R. G. (2000) .The implications of rights to culture in trans-national marketing: An anthropological perspective. High Plains Applied Anthropologist, 2(20), Fall.

25. Aminu, S. A. (2013). Challenges Militating against Adoption of Online Shopping in Retail Industry in Nigeria. Journal of Marketing Management, 1(1), 23-33.

26. Delafrooz, N., Paim, L. H., \& Khatibi, A. (2011). Understanding Consumer's Internet Purchase Intention in Malaysia. African Journal of Business Management, 5(3), 2837-2846. https://doi.org/10.5897/AJBM10.1266

27. Rushinek, A., \& Rushinek, S. (2009). E-commerce security measures Ubiquity, 2002(November), 1. https://doi.org/10.1145/763948.76394

28. Fernandez, A., \& Miyazaki, A. (2001). Consumer Perceptions of Privacy and Security Risks for Online Shopping. Journal of Consumer Affairs, 35(1), 27-44. Retrieved from http://www.sciencedirect.com/science/article/B6VG3-475RJF6-1/2/1 b644a64d596b015dfdbcb4e32b881ce

29. Chang, M. K., Cheung, W., \& Lai, V. S. (2005). Literature derived reference models for the adoption of online Information and Management, 42(4), 543-559. https://doi.org/10.1016/S03787206(04)00051-5

30. Forsythe, S. M., \& Shi, B. (2003).Consumer patronage and risk perceptions in Internet shopping. Journal of Business Research, 56(11), 867-875. https://doi.org/10.1016/S0148-2963(01)00273-9

31. Ling, K. C., Chai, L. T., \& Piew, T. H. (2010). Effects of Shopping Orientations, online trust and prior online purchase experience. International Business https://doi.org/10.5539/ibr.v3n3p63s

32. Kim, L. H., Qu, H., \& Kim, D. J. (2009). A study of perceived risk and risk reduction of purchasing air-tickets online. Journal of Travel and Tourism Marketing, 26(3), 203-224 https://doi.org/10.1080/10548400902925031s

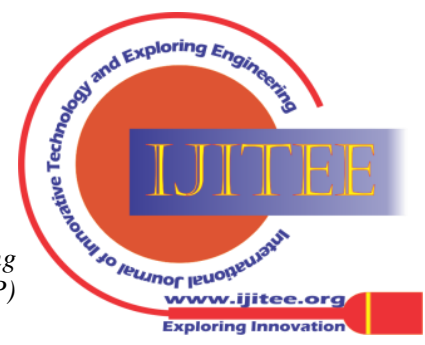




\section{Exploring Challenges of Web-Based Purchasing}

33. Moore, S., \& Mathews, S. (2006). An exploration of online shopping cart abandonment syndrome - A matter of risk and reputation. Journal of Website Promotion, 2(1-2), 71-88. https://doi.org/10.1080/15533610802104141

34. Almousa, M. (2013). Barriers to E-Commerce Adoption: Consumers' Perspectives from a Developing Country. IBusiness, 05(02), 65-71. https://doi.org/10.4236/ib.2013.52008

35. Visser, E., \& Lanzendorf, M. (2004). E-Commerce: A Literture Review. Tidjdschrift Voor Economische En Sociale Geografie, 95(2), 189-205. https://doi.org/10.1111/j.0040-747X.2004.00300.x

36. Kalia, P., Kaur, N., \& Singh, T. (2016). E-Commerce in India: Evolution and Revolution of Online Retail. E-Retailing Challenges and Opportunities in the Global Marketplace, i, 99-120.

37. Wolfinbarger, M., Gilly, M. C., Wolfinbarger, M., \& Gilly, M. C. (2001). shopping online for freedom and Fun. California Mnagement Review, 43(2)

38. Siu, N. Y.-M., \& Cheng, M. M.-S. (2001). A Study of the Expected Adoption of Online Shopping-The Case of Hong Kong. Journal of International Consumer Marketing, 13(3), 87-106. doi:10.1300/j046v13n03_06

39. Kolesar, M. B., \& Galbraith, R. W. (2000). A services-marketing perspective on e-retailing: Implications for e-retailers and directions for further research. Internet Research, 10(5), 424-438. https://doi.org/10.1108/10662240010349444

\section{Authors Profile}

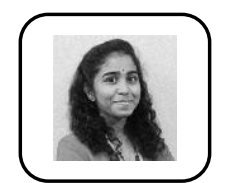

Santhia Nadesan is with school of Industrial Management of Universiti Malaysia Pahang, in Malaysia. Her research interest is in Technology management. She is currently working a research on online-shopping.

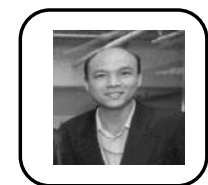

Choo Wou Onn is Dean and assoc. professor of Faculty of information technology, INTI international university, Malaysia. He has published many research reports and articles in information technology and E-commerce fields.

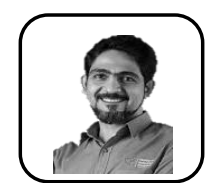

Shahryar Sorooshian is an associate professor with Universiti Malaysia Pahang, Malaysia. He has published many research reports and articles.

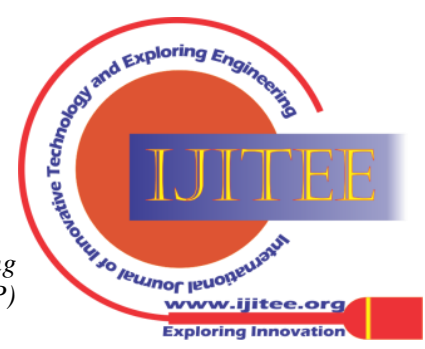

